\title{
Pedestrian Perception about Facility of Pedestrian Crossings
}

\author{
Agah Muhammad Mulyadi \\ Institute of Road Engineering, Ministry of Public Works and Housing. Jl. A.H. Nasution No. 264 Bandung, 40294, Indonesia
}

\begin{abstract}
Pedestrians are vulnerable road user which have potential conflicts with vehicles, especially when pedestrians crossing the road. The number of accidents which was involving pedestrians crossing on the roads were relatively high. Data showed that accidents which were involving pedestrians in Indonesia were 3878 events 1 . The purpose of this study is to determine the needs of pedestrians on the crossing facility and how pedestians desired types of crossing facilities. Data were collected by questionnaire distribution and interviews to the pedestrians. Collecting data and information were conducted in Bandung. Perception of comfort on each type of crossing facility, the majority of respondents choose pelican crossing and crossings with creative road marking with the highest comfort $50 \%$ and $51 \%$ respectively. Respondents' perception on the secure of each types of crossing facility is to assume that overpass/underpass has the highest secure pedestrian crossing by $48 \%$. In addition, the recommendation of types of pedestrian crossing on Jalan Asia Africa Rd and Aceh Rd are pelican crossing on weekday and overpass/underpas at the weekend based on $\mathrm{PV}^{2}$ formula.
\end{abstract}

\section{Introduction}

Walking is the simplest transportation mode in daily activities. Every road which used for public shall be equipped with facilities for bicycles, pedestrians, and persons with disabilities1. Pedestrians is a vulnuarble road user, therefore the safety factor must be improved. Accidents that occur between pedestrians and motor vehicles are common nowadays. Pedestrians accidents usually occurs whereas there are no crossing facility for pedestrians on the road, thus pedestrian cross the roads without crossing facility and the they facing the risk hit by vehicles. Pedestrians who hited by vehicles with travel speed of more than $64.4 \mathrm{~km} / \mathrm{h}$ have a death risk by $85 \%^{2}$.

Pedestrians need facilities that serve to protect pedestrians from conflicts with motor vehicles, thereby increasing the sense of security for both pedestrians and motorists.. The crossing pedestrian facility is part of road which shows by difference surface path, difference textures, or different colors in order to make it contrast so it is easily to recognize by pedestrians or vehicles rider. $^{3}$. Basically, pedestrian crossing facilities are divided into two types, there first is pedestrian crossing at grade and the second is overpass/underpass pedestrian crossing. The choice of pedestrian crossing facilities should also consider pedestrian needs factors, which consist of internal factors such as age, gender, or willingness to using pedestrian facilities. .

\section{Figures and tables}

Roads are road transport infrastructures covering all sections of roads, including auxiliary buildings and equipment intended for traffic, located on soil surface, above ground level, below ground level and/or water, and above water level, except railroads, lorries, and cable roads. ${ }^{5}$

Pedestrians are part of the physical element of urban design. ${ }^{6}$ Each pedestrian needs to walk on the road safely, and is fun, hence its needed pedestrian infrastructure to walking along the road i.e pedestrian sidewalk and pedestrian crossing. The pedestrian facilities were builded to provide for pedestrians in order to improve the smoothness, safety, and comfort of pedestrians. Pedestrian facilities provided for pedestrians are classified into two types: ${ }^{7}$

\subsection{At Grade Pedestrian Crossing.}

\subsubsection{Zebra Cross}

its distinguishing feature is alternating dark and light stripes on the road surface, resembling the coat of a zebra as shown in Figure 1. 


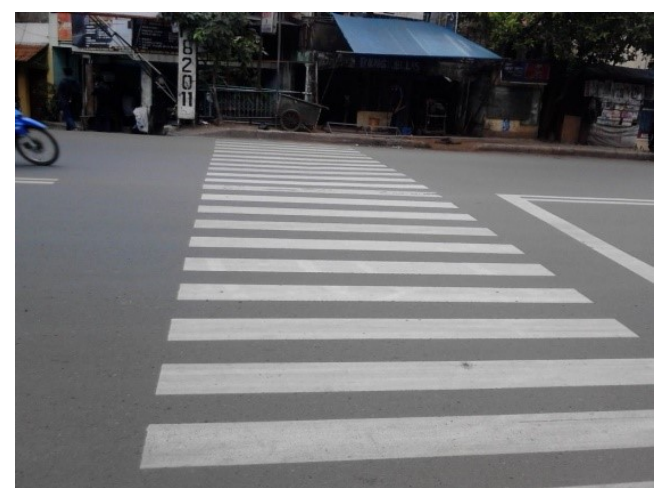

Fig. 1. Zebra Cross

\subsubsection{Pelican Crossing}

Pelican Crossing features a pair of poles each with a standard set of traffic lights facing oncoming traffic, a push button and two illuminated, colored features a pair of poles each with a standard set of traffic lights facing oncoming traffic, a push button and two illuminated, colored pictograms facing the pedestrian from across the road as shown in Figure 2.

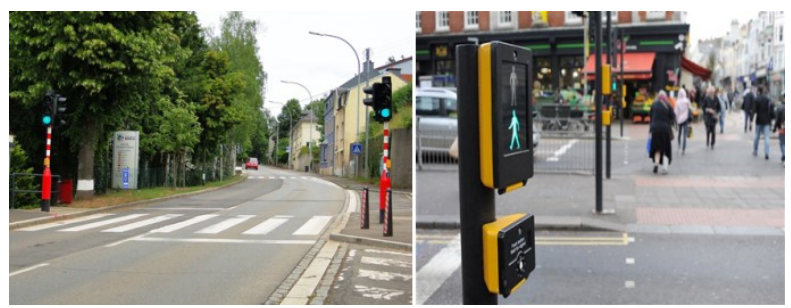

Fig. 2. Pelican Crossing

\subsubsection{Crossings with creative markers}

Crossings with creative markers declared with creative road marking and show by contrast colors that can attract attention from road users as shown in Figure 3.

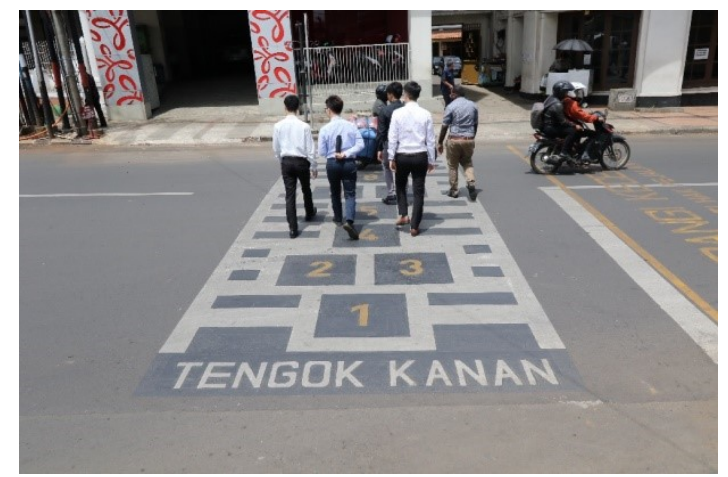

Fig. 3. Crossings with creative markers

\subsection{At Grade Pedestrian Crossing.}

Pedestrian overpasses and underpasses allow for the uninterrupted flow of pedestrian movement separate from vehicle traffic as shown in Figure 4.

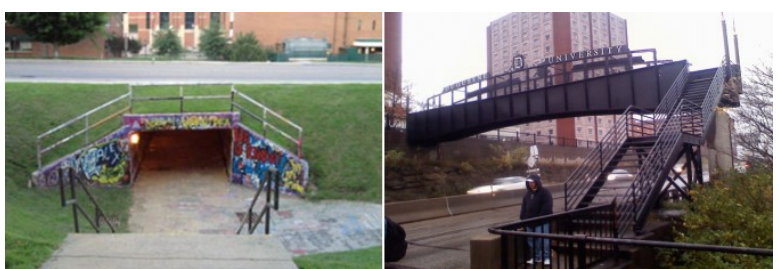

Fig. 4. Pedestrian overpasses and underpasses

The determination of a non-level crossings facility shall be in accordance with the conditions of road traffic being reviewed. The following method of determining the crossing facility is not-level ${ }^{11}$. On the road with a plan travel speed above $75 \mathrm{~km} /$ hour. In strategic areas where waders are not allowed to cross the road, except only on the bridge. $\mathrm{PV}^{2}>5 \times 108$ with $\mathrm{P}>100$ person / hour and $\mathrm{V} 5000 \mathrm{pcu} /$ hour. The V value is taken from the average current value during the $4 \mathrm{hrs}$. Selection of Pedestrian Crossing Facility based on $\mathrm{PV}^{2}$ Formula is shown in Table 1.

Table 1. Setting Word's margins.

\begin{tabular}{|c|c|c|c|}
\hline $\mathbf{P V}^{\mathbf{2}}$ & $\mathbf{P}$ & $\mathbf{V}$ & $\begin{array}{c}\text { Crossing Facility } \\
\text { Recommendation }\end{array}$ \\
\hline $\begin{array}{c}>5 \mathrm{x} \\
10^{8}\end{array}$ & $100-1250$ & $\begin{array}{c}2,000- \\
5,000\end{array}$ & Zebra Cross \\
\hline$>10^{10}$ & $\begin{array}{c}3,500- \\
7,000\end{array}$ & $400-750$ & Pelican Cross \\
\hline $\begin{array}{c}>5 \mathrm{x} \\
10^{9}\end{array}$ & $100-1,250$ & $>5,000$ & Pelican Cross \\
\hline $\begin{array}{c}>5 \mathrm{x} \\
10^{9}\end{array}$ & $>1,250$ & $>2,000$ & Pelican Cross \\
\hline$>10^{10}$ & $100-1,250$ & $>7,000$ & Overpass \\
\hline$>10^{10}$ & $>1,250$ & $>3,500$ & Overpass \\
\hline
\end{tabular}

\section{Research methods}

In this research method of data analysis to be used is quantitative method. Meanwhile data collection techniques that using in this research community perception of pedestrian path in Bandung by interviewing, observation, and distribute the questionnaires. This research to be conducted by using quantitative analysis will be further divided into several analysis based on the needs and field conditions. Analysis to be conducted in this research includes descriptive statistical analysis. Descriptive statistics are the process of collecting and summarizing the data, as well as attempts to describe the various important characteristics of the organized data. ${ }^{8}$

The data collection activities in this study mainly were collected by distributing questionnaires. Questionnaires will be given to respondents related to this research are pedestrian path users who have experiences using pedestrian path. Sampling technique to be taken in this research is accidental systematic sampling. The accidental sampling technique is performed when the selection of sample members is made against any person or object that happens to exist or be encountered. The advantage of this sampling technique is fast and easy. ${ }^{9}$ While the weakness is less representative. Then the number of samples to be used is 
120 respondents. This amount is determined based on the consideration of the accuracy of research results to be representative and can represent the existing population in the study area. Furthermore, the number of respondents is divided based on certain times between weekend and weekdays to obtain data distribution. Primary survey data is shown in Table 2.

Table 2. Primary Survey Data.

\begin{tabular}{|c|c|c|c|c|c|}
\hline Day & $\begin{array}{c}\text { Time } \\
\text { Session }\end{array}$ & Time & Locations & $\begin{array}{l}\text { Number of } \\
\text { respondents }\end{array}$ & City \\
\hline \multirow{3}{*}{$\begin{array}{c}\text { Sun } \\
\text { day } \\
\text { and } \\
\text { Mo } \\
\text { nda } \\
\text { y }\end{array}$} & Morning & $\begin{array}{c}06.00- \\
08.00\end{array}$ & \multirow{3}{*}{$\begin{array}{c}\text { Asia } \\
\text { Africa Rd } \\
\text { and Aceh } \\
\text { Rd. }\end{array}$} & 20 & \multirow{3}{*}{$\begin{array}{c}\text { Ban } \\
\text { dun } \\
g\end{array}$} \\
\hline & Day & $\begin{array}{l}12.00- \\
14.00\end{array}$ & & 20 & \\
\hline & Noon & $\begin{array}{l}15.00- \\
17.00\end{array}$ & & 20 & \\
\hline
\end{tabular}

Analysis to be used is the frequency distribution analysis for each parameter. The frequency distribution in principle is to organize the data into several classes of the same data, therefore that each class can describe the characteristics of the existing data. ${ }^{10}$ At this stage the public opinion of the pedestrian path is summed and percentage is made for each community choice.

\section{Pedestrian perception analysis}

The result of perceptual analysis of the questionnaire results, the most widely found pedestrian path users are in productive age. This is because most of users in the productive age are still able to do many walking activities when compared to road users who in the old age or children. The classification of productive age is aged 15-30 years old and 31-45 years old, the result of the distribution of data obtained by domination at productive age is $86.67 \%$. The distribution data by age of respondents is shown in Table 3.

Table 3. Distribution of data by age of respondents

\begin{tabular}{|c|c|c|}
\hline Age Clasification & Frequency & Percentage \\
\hline$<15$ & 1 & $0.83 \%$ \\
\hline $15-30$ & 86 & $71.67 \%$ \\
\hline $31-45$ & 18 & $15.00 \%$ \\
\hline $46-60$ & 12 & $10.00 \%$ \\
\hline$>60$ & 3 & $2.50 \%$ \\
\hline Total & $\mathbf{1 2 0}$ & $\mathbf{1 0 0} \%$ \\
\hline
\end{tabular}

In addition, the analysis based on the education background, found that most respondent have education background are high school and college/universities is $86.67 \%$. The distribution data base on education background is shown in Table 4.
Table 4. Distribution of data based on the education background

\begin{tabular}{|c|c|c|}
\hline $\begin{array}{c}\text { Education } \\
\text { Background }\end{array}$ & Frequency & Percentage \\
\hline $\begin{array}{c}\text { Never been } \\
\text { Studied }\end{array}$ & 0 & $0.00 \%$ \\
\hline Primary school & 4 & $3.33 \%$ \\
\hline $\begin{array}{c}\text { Junior high } \\
\text { school }\end{array}$ & 16 & $13.33 \%$ \\
\hline $\begin{array}{c}\text { Senior High } \\
\text { School }\end{array}$ & 85 & $70.83 \%$ \\
\hline College & 15 & $12.50 \%$ \\
\hline Total & $\mathbf{1 2 0}$ & $\mathbf{1 0 0} \%$ \\
\hline
\end{tabular}

Respondents characteristics are users who are in the ages that tend to perform recreational activities or shopping, consequently that in line with the condition of the pedestrian path which close with shopping centre and public park. Analysis level of income show most of respondents have income below 1 million rupiah is $81.67 \%$. This is correlation because most of respondents still study in the school or college, accordingly, they do not have their own income, or if they work with that level of education, they will have an average income less than 1 million rupiah. Distribution of respondents income is shown in Table 5.

Table 5. Distribution of data based on respondents income

\begin{tabular}{|c|c|c|}
\hline $\begin{array}{c}\text { Respondents' Income } \\
\text { (Rp.) }\end{array}$ & Frequency & Percentage \\
\hline$<1,000,000$ & 98 & $81.67 \%$ \\
\hline $1,000,000-2,500,000$ & 10 & $8.33 \%$ \\
\hline $2,500,001-4,000,000$ & 8 & $6.67 \%$ \\
\hline $4,000,001-7,000,000$ & 3 & $2.50 \%$ \\
\hline$>7,000,000$ & 1 & $0.83 \%$ \\
\hline Total & $\mathbf{1 2 0}$ & $\mathbf{1 0 0} \%$ \\
\hline
\end{tabular}

Activities near the pedestrian facility at the time of distributing the questionnaire should be known to measure the typical journey of a pedestrian. Most of respondents came to Asia Afrika Road to recreation and leisure. At the location of data collection in Bandung as much as $48 \%$ of respondents who have a reason accidentally visited the location of pedestrian facilities. Distribution of respondents activity in the area around the pedestrian crossing is shown in Table 6 .

Table 6. Distribution of trip purpose

\begin{tabular}{|c|c|c|}
\hline Trip Purpose & Frequency & Percentage \\
\hline Sightseeing & 25 & $20.84 \%$ \\
\hline Shopping & 10 & $8.33 \%$ \\
\hline Waiting for Public Transport & 5 & $4.17 \%$ \\
\hline Accidentally Visited this place & 57 & $47.50 \%$ \\
\hline Meal time & 8 & $6.67 \%$ \\
\hline Working & 15 & $12.50 \%$ \\
\hline Total & $\mathbf{1 2 0}$ & $\mathbf{1 0 0 \%}$ \\
\hline
\end{tabular}


The results of pedestrian knowledge about types of pedestrian crossing facilities i.e zebra cross, pelican cross, creative road marking cross, and overpass and underpass. Crossing facilities of zebra cross and Overpass/ Underpass pedestrian crossing is the most familiar crossing facility that $100 \%$ of respondents know this facility. Meanwhile, the type of pelican cross and crossings with creative markers have already known by $53.33 \%$ and $100 \%$ respectively. Distribution of respondents knowledge is shown in Table 7.

Table 7. Distribution of data by knowledge about types of pedestrian crossing

\begin{tabular}{|c|c|c|c|c|}
\hline $\begin{array}{c}\text { Pedestrian } \\
\text { Crossing } \\
\text { Facility }\end{array}$ & $\begin{array}{c}\text { Respond } \\
\text { ent has } \\
\text { already } \\
\text { known }\end{array}$ & $\begin{array}{c}\text { Percent } \\
\text { age (\%) }\end{array}$ & $\begin{array}{c}\text { Respond } \\
\text { ent did } \\
\text { not } \\
\text { know }\end{array}$ & $\begin{array}{c}\text { Percent } \\
\text { age (\%) }\end{array}$ \\
\hline Zebra Cross & 120 & $\begin{array}{c}100.00 \\
\%\end{array}$ & 0 & $0.00 \%$ \\
\hline $\begin{array}{c}\text { Pelican } \\
\text { Crossing }\end{array}$ & 64 & $53.33 \%$ & 56 & $46.67 \%$ \\
\hline $\begin{array}{c}\text { Crossings with } \\
\text { creative } \\
\text { markers }\end{array}$ & 89 & $74.17 \%$ & 31 & $25.83 \%$ \\
\hline $\begin{array}{c}\text { Overpass/Und } \\
\text { erpass } \\
\text { Pedestrian } \\
\text { Crossing }\end{array}$ & 120 & 100.00 & 0 & $0.00 \%$ \\
$\%$ & & & \\
\hline
\end{tabular}

The question that states whether the respondent always cross the road by using the pedestrian crossing facilities, the majority respondent's answer is sometimes as $34 \%$, often as $30 \%$, rare as $19 \%$, very often as $9 \%$ dan very rare as $8 \%$. These results are needed to know the respondent's awareness about road safety. In addition, by using pedestrian crossing facility, By crossing through pedestrian fasilities will encourage others people to do the something. Figure 5 shown the piechart about frequency of cross the road by using the pedestrian crossing facilities.

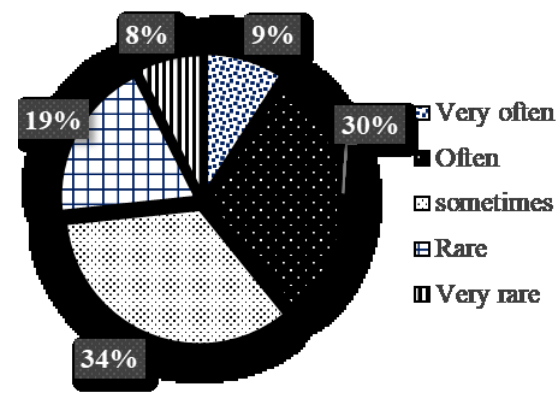

Fig. 5. Respondents cross the road by using the pedestrian crossing facilities

Data analysis with statistical analysis method is data response to performance of each crossing facility on the Asia Africa Rd and Aceh Rd based based on secure and comfort feeling with score as shown in Table 8 .
Table 8. Classification fot Secure and Comfort Pedestrian Crossing

\begin{tabular}{|c|l|}
\hline Score & Classification \\
\hline 1 & Very High \\
\hline 2 & High \\
\hline 3 & Netral \\
\hline 4 & Low \\
\hline 5 & Very Low \\
\hline
\end{tabular}

Distribution of secure feeling using of pedestrian crossing is shown in Figure 6.

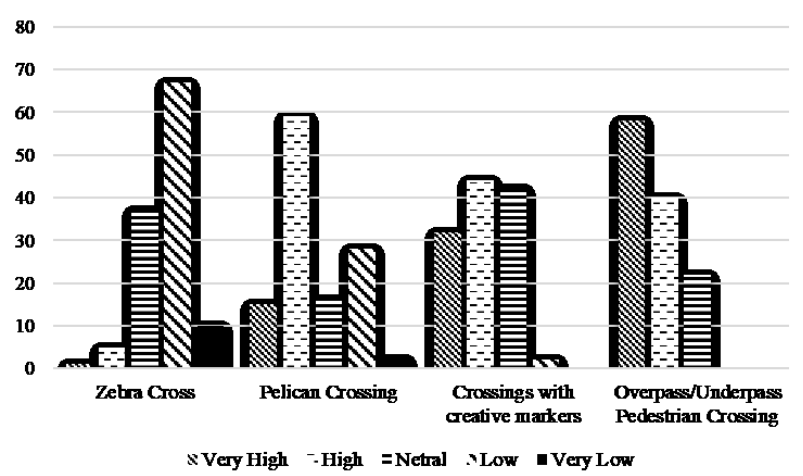

Fig. 6. Distribution of Secure Feeling Using of Pedestrian Crossing

Based on the results of data processing at each pedestrian crossing facility it is obtained for the perception of secure feeling itself. At the zebra cross facility the majority of respondents felt a low secure by $55.83 \%$. Furthermore, pelican crossing facility has a perception of high secure by respondent is $49.17 \%$. The result of high secure perception also obtained by pedestrian crossings with creative markers facility with $36.67 \%$. Meanwhile, pedestrian crossing overpass/ underpass facility has very high secure perception with majority of respondents choose $48.33 \%$. So that, they feel very safe and secure when crossing by using pelican cross and underpass/overpass crossing. Distribution of comfort feeling using of pedestrian Crossing is shown in Figure 7.

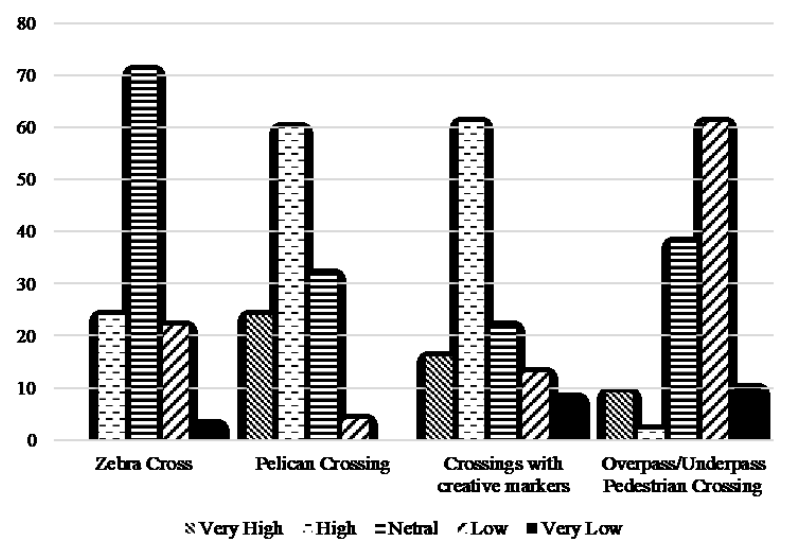


Fig. 7. Distribution of Comfort Feeling using of Pedestrian Crossing

Respondents tend to using crossing facilities if it can be achieved easily, free of obstacles and there is separator in the middle of the roas as waiting area.

The result of respondent's perception about comfort feeling for each types of pedestian crossing facility is the zebra cross facility the majority of respondents feel the normal by $59.17 \%$ while Pelican Crossing facility has a perception of comfort are high comfort by $50.00 \%$. On the other hand, high comfort perception is obtained by crossings with creative markers facility with $50.83 \%$ while Crossing Overpass/Underpass facility has low comfort perception with majority of respondents by $50.83 \%$.

The analysis for the questionnaire data is done by calculating the average value of the respondent's answer in every variable in the questionnaire. In addition, average values and mode values can be obtained by using the statistical analysis method on each survey zone. Table 9 show the average value and mode value for each types of pedestrian crossing.

Table 9. Average Value and Mode Value

\begin{tabular}{|c|c|c|c|c|}
\hline \multirow{2}{*}{ Crossing Facility } & \multicolumn{2}{|c|}{ Secure } & \multicolumn{2}{c|}{ Convenience } \\
\cline { 2 - 5 } & $\begin{array}{c}\text { Average } \\
\text { Value }\end{array}$ & $\begin{array}{c}\text { Value } \\
\text { mode }\end{array}$ & $\begin{array}{c}\text { Average } \\
\text { Value }\end{array}$ & $\begin{array}{c}\text { Value } \\
\text { mode }\end{array}$ \\
\hline Zebra Cross & 2.13 & 2 & 3.87 & 3 \\
\hline Pelican Crossing & 4.10 & 4 & 4.03 & 4 \\
\hline $\begin{array}{c}\text { Crossings with } \\
\text { creative markers }\end{array}$ & 3.60 & 2 & 4.03 & 4 \\
\hline $\begin{array}{c}\text { Overpass/Underpass } \\
\text { Pedestrian Crossing }\end{array}$ & 4.30 & 4 & 2.57 & 2 \\
\hline
\end{tabular}

To determine the types of crossing facility in each survey zone, the determination of pedestrian crossing facilities is used, thus that the types of pedestrian crossing facilities can be determined as shown in Table 10.

Table 10. Recommendation Crossing Facility

\begin{tabular}{|c|c|c|c|c|}
\hline $\begin{array}{c}\text { Time } \\
\text { Surve } \\
\mathbf{y}\end{array}$ & $\begin{array}{c}\mathbf{P} \\
\text { (Pedestrian// } \\
\text { hour) }\end{array}$ & $\begin{array}{c}\mathbf{V} \\
\text { (vehicle/h } \\
\text { our) }\end{array}$ & $\mathbf{P V}^{\mathbf{2}}$ & $\begin{array}{c}\text { Crossing } \\
\text { Facility } \\
\text { Recomend } \\
\text { ation }\end{array}$ \\
\hline $\begin{array}{c}\text { Week } \\
\text { day }\end{array}$ & 203 & 7010 & $\begin{array}{c}9.97 \mathrm{E} \\
+09\end{array}$ & $\begin{array}{c}\text { Pelican } \\
\text { Crossing }\end{array}$ \\
\hline $\begin{array}{c}\text { Weeke } \\
\text { nd }\end{array}$ & 562 & 5994 & $\begin{array}{c}2.01 \mathrm{E} \\
+10\end{array}$ & Overpass \\
\hline
\end{tabular}

The analysis result, it is found that the recommendation of crossing facility on weekday is pelican crossing with $\mathrm{PV}^{2}$ result of $9.97 \mathrm{E}+09$. Further recommendation of crossing facility at the weekend is pelican crossing with $\mathrm{PV}^{2}$ result of $2.01 \mathrm{E}+10$.

\section{Conclusion}

Based on the analysis, followings are the conclusions:

- The type of crossing facility that is most familiar with the respondent is the type of Zebra Cross and Overpass/Underpass. Whereas the majority of respondents sometimes using pedestrian facilities.

- Respondents' perception on the secure of each types of crossing facility is to assume that overpass/underpass has the highest secure pedestrian crossing.

- Perception of comfort on each type of crossing facility, the majority of respondents choose pelican crossing and crossings with creative road marking with the highest comfort level compared with overpass/underpass is less comfortable.

- Based on the analysis $\mathrm{PV}^{2}$ result, the recommendation of types of pedestrian crossing on Jalan Asia Africa $\mathrm{Rd}$ and Aceh $\mathrm{Rd}$ are pelican crossing on weekday and overpass/underpas at the weekend.

\section{References}

1. Pemerintah Republik Indonesia, 2009, Undangundang Nomor 22 Tahun 2009 tentang Lalu Lintas dan Angkutan Jalan, Jakarta.

2. Korlantas-IRSMS Police, 2017. Jumlah Kecelakaan yang melibatkan pejalan kaki. Jakarta.

3. AASHTO, 2004. Guide for the Planning, Design, and Operation of Pedestrian Facilities. American Association of State and Highway Transportation Officials.

4. Hidayat. Edwin, 2012. Selection of Crossing Facilities Based on Critical Gap (Case Study Dharmawangsa Street, Surabaya). Cibinong.

5. Pemerintah Republik Indonesia, 2004, UndangUndang Nomor 38 Tahun 2004 tentang Jalan, Jakarta.

6. Iswanto, Danoe. 2006. Jurnal Ilmiah Perancangan Kota dan Pemukiman Vol.5 No 1. Maret,2006. Pengaruh Elemen - Elemen Pelengkap Jalur Pedestrian Terhadap Kenyamanan Pejalan Kaki ( Studi Kasus : Penggal Jalan Pandanaran, Dimulai Dari Jalan Randusari Hingga Kawasan Tugu Muda ), Semarang.

7. Direktorat Jenderal Bina Marga, 1995. Tata Cara Perencanaan Fasi- litas Pejalan Kaki di Kawasan Perkotaan. Jakarta.

8. Supangat, Andi. 2007, Statistika Dalam Kajian Deskriptif, Inferensial dan Nonparametik, Kencana perdana Group, Jakart

9. Santoso, Singgih. 2003. Statistk Deskriptif. Yogyakarta. Penerbit ANDI.

10. Putri, Pinkan Amelinda K dan Denny Zulkaidi. 2013. "Faktor yang Mempengaruhi Permint aan Terhadap Penyediaan Jalur Pejalan Kaki Pada Suatu Kawasan" dalam jurnal Perencanaan Wilayah dan Kota B 
SAPPK V2N3. Hlm: 595-603. Bandung: Sekolah Arsitektur, Perencanaan dan Pengembangan Kebijakan ITB.

11. Direktorat Jenderal Bina Marga. 1999. Pedoman Perencanaan Jalur Pejalan Kaki Pada Jalan Umum. Jakarta. 